\title{
The role of teacher characteristics in an educational standards reform
}

\author{
Julia Zuber ${ }^{1} \cdot$ Herbert Altrichter ${ }^{1}$
}

Received: 3 July 2017 / Accepted: 16 April 2018 / Published online: 2 May 2018

(C) The Author(s) 2018

\begin{abstract}
The policy of performance standards aims for quality improvement in schools by stimulating teachers to plan and organize their teaching according to competence-based performance standards (competence-based teaching) and to use performance data feedback from national standard-based assessments for evidence-based teaching development. The research so far indicates that many teachers seem to make less use of performance standards and data feedback than expected and to use it in partly unintended ways. Cognitive adaption theory suggests that the reaction of individuals to change is strongly influenced by individual characteristics. In particular, self-efficacy, locus of control, and positive affectivity have been found to foster openness to change and therefore enable participation in change. Following this approach, the paper explores to what extent teachers' use of performance standards and data feedback can be linked to individual dispositions such as self-efficacy, perceived control, and positive affectivity. Using data from Austrian primary teachers, the results suggest that self-efficacy and positive affectivity foster openness to the educational standards reform which in turn increases the likelihood of teachers' participation in competence-oriented teaching and data use.
\end{abstract}

Keywords Dispositions · Performance standards · Data use $\cdot$ Competence-based teaching $\cdot$ School improvement $\cdot$ Self-efficacy $\cdot$ Positive affectivity

\section{Introduction}

During the last years, many European educational systems have introduced new policies to reform and improve their educational systems. One of the most prominent reform

Julia Zuber

julia.zuber@jku.at

Herbert Altrichter

herbert.altrichter@jku.at

1 Linz School of Education, Johannes Kepler University Linz, Linz, Austria 
policies is the so-called performance standard policy, which aims for improvement of teaching quality and student performance (Campbell and Levine 2009; Maag Merki 2016). Teachers are expected to change their instruction towards competence-oriented teaching and use feedback data that is provided by nationwide testing of student performance for improving their teaching. By now, the outcomes of this reform fall short of expectations. While some changes in instruction towards more competence-oriented teaching among teachers have been observed (Zeitler, Heller, and Asbrand 2012), there is very little use of data feedback for classroom improvement (Datnow and Hubbard 2016; Maier and Kuper 2012). Research investigating the reasons for the disappointing impact has mainly focussed on the policy and organizational level of the reform, investigating the role of support structures, data systems, and leadership (Anderson et al. 2010; Means et al. 2009; Wayman et al. 2012).

Contrary to this focus on the macro and meso level of educational reforms, a more person-oriented perspective on change processes can be observed in recent years in a variety of fields. In particular, personal dispositions and their influence in organizational change processes have been put on the research agenda assuming that successful coping with change depends on the psychological predispositions of individuals experiencing the change. This approach has been widely used for studying a variety of aspects of occupational change such as dispositions in different sectors (public vs. private), in different groups (managers, workers, etc.), and in different occupations (e.g., Härenstam et al. 2004; Sutin and Costa 2010; Tummers et al. 2012). Thereby, strong evidence was accumulated that organizational change and work behavior are to a certain extent dispositionally based. However, so far, very little research has used this psychological focus for investigating change processes in the education system, in particular for change caused by educational reforms. The paper at hand intends to take this perspective: It will explore to what extent teachers' reactions to the change processes caused by educational standard reform can be predicted as a function of personality characteristics. Thereby, we aim at transferring a well-established theory of cognitive adaption into the context of education, enabling a theory-guided approach of investigating the relationship between individual characteristics and reform take-up. In particular, we will focus on the individual characteristics self-efficacy, positive affectivity, and locus of control. In the following section, we will review the literature on individual coping with organizational change and on potential predictors. Subsequently, the main features of the educational standards reform and its possible relationship to dispositional characteristics are discussed.

\subsection{Individual dealing with organizational change}

In our society, large-scale changes such as changes in technology, production methods, or compensation systems are present in almost all occupational fields. However, many of these change efforts fall short of expectations or fail altogether. Research on occupational changes and its antecedents suggests that organizational change, regardless of the specific occupation or occupational sector, is viewed as a major stressor in organizational life and is often associated with negative outcomes such as drop out, conflicts, and threats to psychological well-being (Ashford 1998; Schweiger and DeNisi 1991). Organizational members have been found to avoid the negative consequences of changes (i.e., increased workload, threats to well-being, etc.) by objecting to the change proposal altogether 
("resistance to change"; see, e.g., Nord and Jermier 1994). Potential antecedents of these individual reactions to change have been assumed to be associated with both the individual $\mathrm{him} /$ herself as well as with the individual's environment (cf. Lewin 1951).

A number of studies found that employees' behavior (or non-behavior) in organizational change can be predicted by individual characteristics. In particular, three major dispositions turned out to be highly predictive of individuals' coping with change.

- Locus of control is the perception of an individual of her or his ability to exercise control over the environment (Rotter 1966; Lau and Woodman 1995). Actors characterized by an "internal locus of control" believe they have control over their environment and their personal success, while those with an "external locus of control" view their lives as controlled by external factors such as chance or powerful others.

- Self-efficacy has been defined as a generative capability that enables individuals to integrate cognitive, social, emotional, and behavioral skills to accomplish particular objectives (Bandura 1997).

- Positive affectivity is typically manifested as well-being, confidence, energy, and affiliation (Judge et al. 1999, p. 109). Very similar to the concept of optimism, positive affectivity is associated with a positive world view.

Cognitive adaptation theory (Aspinwall and Taylor 1992; Taylor and Brown 1988) may be used for explaining the influence of these constructs in change processes. When individuals experience change, they respond with cognitively adaptive efforts that enable them to return to or even improve their previous level of psychological functioning (Taylor 1983). High self-efficacy, internal locus of control, and positive affectivity help to gain control by enabling an individual to see change in the best light possible. In the literature, this shift towards a favorable perception of change has been conceptualized as "openness to change" (e.g., Judge et al. 1999). High levels of self-efficacy, perceived control, and wellbeing foster a positive attitude towards change which in turn enhances individuals' compliance to participate in change processes. Strong empirical support for this theory has been accumulated in a variety of different contexts such as organizational change, health, and life-event research (Ashforth and Lee 1990; Callan et al. 1994; Holahan and Moos 1987; Judge et al. 1999; Lau and Woodman 1995; Nelson et al. 1995). Supporting this theory from another perspective, Major et al. (1998) viewed self-concept, optimism, and perceived control as variables highly correlated to self-efficacy, perceived control, and well-being; together, they form the characteristics of a "resilient personality" which enables individuals to react positively to challenging situations (see also Gu and Day 2007).

Besides these main constructs, some other dispositions have been associated with behavioral outcomes during change. For example, Judge et al. (1999) found that, besides self-concept-related constructs (locus of control, positive affectivity, and selfefficacy), risk tolerance including low risk aversion and tolerance for ambiguity) was predictive of individuals coping productively with change (see also Budner 1962; Slovic 1972). Miller, Johnson, and Grau (1994) identified high levels of need for achievement and sensation seeking (Zuckerman and Link 1968) as important precursors for participating in organizational change. However, these dispositions have only been studied in specific groups (i.e., managers) or specific fields (i.e., private sector) and cannot yet be generalized to different areas. 
In addition to this individual perspective, a variety of contextual variables have been proposed as factors explaining employees' behavior during change. While some antecedents are connected with the outcomes of change (losing or gaining power, job security), others focus on the way in which change is implemented (e.g., amount of information given about the change, social support). However, several studies suggest that implementation aspects are most likely to influence employees' behavior responses (Crino 1994; Skarlicki and Folger 1997; Oreg 2006). Similar to the assumed role of disposition, these contextual factors also facilitate positive attitude towards change and thereby enable implementation of change (Wanberg and Banas 2000). Detailed, timely, and useful information about intended change has been shown to reduce resistance reactions (Miller et al. 1994; Wanberg and Banas 2000), to improve employee attitude towards change, and to increase willingness to cooperate (Wanberg and Banas 2000). Also, social support (i.e., the availability of another individual to turn to for information, comfort, encouragement, or reassurance) facilitates coping with change and helps building positive attitudes towards change (Shaw et al. 1993; Wanberg and Banas 2000).

In the educational sector, organizational change by educational reforms has been identified as strong predictor for drop out of teaching, increased psychosomatic symptoms (von der Embse et al. 2016), and early retirement (Ryan et al. 2017) indicating that educational change is experienced as a major stressor. Thus, one would expect that individuals react with cognitive adaptation to educational reforms. A closer look the current educational reform policy may give us a fine-grained insight into the changes that are expected and the experiences with implementation known so far.

\subsection{Educational standards policy}

Since the PISA shock in 2001, many European school systems have been reforming their governance structure in order to improve system performance and economy (see Altrichter et al. 2005). A key element of these reforms is the so-called performance standards policy (Maag Merki 2016) which aims for improvement of teaching quality and student performance by stimulating actors at all system levels to "use" the elements of this policy for further developing their practice.

What are the underpinning rationale and the elements of the "performance standards policy"? From the perspective of teachers, ${ }^{1}$ the innovation strategy of this policy is characterized by two lines of (intended) effect (see Altrichter and Kanape-Willingshofer 2012; Altrichter and Gamsjäger 2017):

(1) By explicitly formulating competence-based performance standards, the goals and objectives of teaching and learning (and, thus, the ultimate performance expectations for all actors in the school system) are communicated more clearly than before. This will lead, where necessary, to changes in teaching in favor of "competence-based teaching" which should result in improved student skills and performance. According to this concept, students should acquire competences that encompass not only

\footnotetext{
${ }^{1}$ According to the analysis by Altrichter and Gamsjäger (2017), performance standards may also influence educational practice through actors other than teachers, e.g., through the media, through school management, or through the "stakeholders" of the school. In this article, however, we will concentrate on teachers' use of "performance standards."
} 
expertise in subjects (as required in more traditional, non-competence-based teaching) but also content-specific problem solving abilities (Weinert 2001) and interdisciplinary competences such as social, personal, and methodical skills (Lersch 2010). These competencies are to enable students to master a broad range of situations and demands (Reusser 2014). In order to achieve this, teachers have to develop a "competence-oriented teaching" style (BIFIE 2012). Competence-oriented teaching requires focussing on the acquisition of sustainable competencies rather than on contents only (Blum 2012). According to Neuweg (2015, p. 8), this type of teaching urges teachers to include new teaching material (competence-oriented tasks) into their lessons, to plan their lesson according to the nationally formulated competence standards, and to create specific performance situations allowing students to exercise and test their competencies (see also Lersch 2010). The implementation of "competence-oriented teaching" is accompanied by various "support offers" (such as professional development opportunities, teaching materials, and diagnostic tests) that provide a clearer, action-oriented description of the desired changes.

(2) Nationwide comparative performance tests check the extent to which the competences required by the performance standards (in the main subjects German, and Maths in primary schools) have actually been achieved. This information is processed in such a way that the results of individual system units (e.g., individual classes, schools, regions) can be compared with each other's and several benchmarks (e.g., the national average) and can be fed back to various players in the school system as data feedback. The feedback to teachers includes the average achievement of their class compared to all other classes in the country; "fair comparisons" (taking into account context factors such as migration background of students, socio-economic status of parents, etc.) are provided. Since there is no information on the competencies of individual students available, data feedback cannot be used for individual diagnostic activities but is meant for general improvement of teaching. Data feedback for teachers does not include recommendations for specific changes in their teaching. Rather, it is expected that teachers (individually, in their subject group, or supported by some professional development event) will analyze the results, consult support material (offering, e.g., competence-oriented assignments, diagnostic tests), and, as a consequence, improve their lesson preparation and teaching focussing more strongly on achieving the defined competences.

The evaluation of teachers' reaction to this reform has been quite sobering from a policy perspective. $^{2}$ Many teachers did not engage in this reform but seemed to resist to the change. Only $10 \%$ of the teachers regularly did competence-based lessons during the pilot phase of the implementation of Austrian performance standards (Grillitsch 2010). According to a German study by Maier (2009a; 2009b), less than $20 \%$ of teachers changed their teaching as a consequence of data feedback. If they did so at all, mostly "superficial changes" (e.g., repeating a topic, using assessment formats in teaching) were made, which

\footnotetext{
${ }^{2}$ Even if performance standards seem to be a "traveling policy" which has been taken up in different countries and school systems, we are assuming that similar policies can be of different meaning and lead to different effects when they are embedded in different system contexts (Ozga and Jones 2006; see also Hellrung and Hartig 2013). As we will use empirical data from Austria later on, we will focus our analysis of previous research on results from Germany and Austria, the school systems of which are usually regarded as relatively similar (see the cluster analysis by Windzio et al. 2005).
} 
could be implemented without great effort (Groß Ophoff 2013). Also, cases of nonintended "symbolic and strategic use" of data feedback were found (Hellrung and Hartig 2013): restricting the taught curriculum to test-relevant content, mimicking the multiplechoice performance test formats in classroom tasks and assignments (Kühle and Peek 2007), excluding low-performing students from performance tests Maier 2009a, 2009b). Groß Ophoff (2013) also reported incidents of teachers citing "performance data" to strengthen their position in the interaction with parents and the school management. The ways of data use also proved to be stable over time: Although comparative tests are becoming a routine for actors in schools, the use of data feedback for developing classroom teaching did not increase over the years (Nachtigall and Hellrung 2013).

In view of these disappointing results, several attempts have been made in recent years to identify factors supporting or inhibiting teachers' use of performance data. So far, research has focussed on macro and meso factors of implementation (Maag Merki 2016; Altrichter et al. 2016). We will analyze processes of coping with this educational reform from an individual perspective.

\subsubsection{Context-specific variables}

In general, research has put more attention on mechanism of data use than on implementation of standards and competence-oriented teaching, and even more attention on context variables than on individual characteristics. Among these context factors, "support" has been identified as crucial variable predicting implementation. Wacker (2008) showed that the implementation of competence-oriented teaching was mainly driven by support material providing teaching material and student assignments. The specific relevance of this material may be attributed to the fact that information about "core requirements" provided by the authorities was limited to general descriptions of competences and that teachers were asked to develop the content themselves (see also Grillitsch 2010). For improving data use, support structures enhancing data literacy have been proposed. Teachers' ability to understand and process the performance information provided has been suggested as most influential factor for data use (Helmke 2004). Even those teachers who reported to be open to feedback seemed to find it difficult to process the information on student performance and draw conclusions for improving their teaching. They need competencies to read data from tables and graphics, to establish relationships between data, and to interpret concepts such as "objective reference norm" and "fair comparison" (Koch 2011). Above this type of "data literacy," they also need didactical competencies (such as knowledge about subject matter teaching methodology and competence-oriented teaching) for improving teaching and learning processes (Dubs 2006).

In order to increase data literacy and use of data feedback, feedback formats have been restructured and simplified and various sources of information have been implemented (e.g., Peek and Dobbelstein 2006) which have significantly increased comprehensibility of data feedback (Koch 2011; Hellrung and Hartig 2013). Moreover, training studies suggest that external support explaining statistical results is crucial for enhancing data use (Schildkamp et al. 2016; Vanhoof et al. 2013). Contrary to these findings, external support by resource persons did not result in boosting data use in the Austrian context (Rieß and Zuber 2014). It is worth mentioning that previous studies investigating the role of context variables in data use and competence-oriented teaching usually assumed direct influence of context variables on outcome variables. Cognitive 
adaption theory, however, suggests that context variables influence attitude towards the reform which in turn enables implementation actions.

\subsubsection{Individual characteristics}

Studies investigating the implementation of new teaching styles (e.g., differentiated instruction, Suprayogi et al. 2017) indicate a strong influence of individual characteristics such as self-efficacy for positive attitude formation on implementation processes (Wan 2015). Surprisingly, competence-oriented teaching has, to our knowledge, not been studied under this perspective while data feedback use and its dispositional precursors have received considerable attention.

Attitudes towards the reform have been shown to significantly influence the use of performance data feedback (Ditton and Merz 1999, 2000; Hosenfeld et al. 2008; Kühle and Peek 2007; Maier and Rauin 2006; Peek 2004; Schrader and Helmke 2004; Koch 2011). Attitude formation was reliably predicted by self-efficacy (Pant et al. 2008; Trempler et al. 2012) as well as by contextual factors such as credibility and usefulness of the information provided (Brown and Harris 2009; Coe 1998; Patton 2003; Groß Ophoff 2013; Kersting 2003).

Wacker (2008) investigated the role of positive affectivity. He reported that a high degree of occupational stress as a result of a reform will make its implementation less likely, while high degrees of professional satisfaction will increase the chance of implementation. However, these findings were directly linked to behavior but not linked to attitude formation as mediator as one would expect it from cognitive adaption theory.

The perceived locus of control has also been linked to data feedback use. If teachers perceive comparative tests as "external control," this will have a detrimental effect on classroom development (Kühle 2010; Kuper and Hartung 2007). While accountability pressure will also lead to some use of data feedback, only minimal effort is invested in order to receive rewards and avoid sanctions (Ryan and Brown 2005). Contrarily, high levels of internal locus of control have been found to enhance intrinsic motivation and teachers remain motivated for the use of the data feedback in a long-time perspective (Schellenbach-Zell et al. 2008).

In sum, the results presented above indicate that teachers' coping with educational standards reform is mainly characterized by less participation than expected. With regard to cognitive adaption theory, one would expect that the behavior during the reform would be predictable through the following mechanism: Individual dispositions such as self-efficacy, perceived control, and affectivity serve as precursors for a positive attitude which in turn should facilitate reform implementation. Additionally, context variables such as support or environmental demands additionally influence openness to a reform. So far, causal mechanisms underlying the implementation of educational standard reform on the individual level have not been investigated in educational research, although there is some indication that cognitive adaption theory may be useful in explaining educational reform implementation (e.g., Pant et al. 2008). Thus, the present study aims at linking the results from organizational change research to educational reform implementation in order to investigate the role of dispositions for predicting behavior during a reform more thoroughly. This extends previous research in at least three important ways. First, behavior during an educational reform is investigated following a theory of organizational change whereby the interplay of individual characteristics is taken into account, in particular, the influence of 
dispositional characteristics on attitude and behavioral outcome. Second, context factors are systematically integrated into the research model, following the assumption that they have specific influence on attitudes to change rather than assuming direct influence on outcome variables. Third, for the first time, behavioral responses during educational standards reform are studied with respect to intended outcome behaviors, i.e., competence-oriented teaching and use of data feedback for classroom improvement.

\subsection{Purpose and research questions}

The present study aims at investigating to what extent individual characteristics are predictive of teachers' behavior in the context of an educational reform. The literature points to a strong dispositional influence on behavioral outcome; in particular, characteristics related to self-concept, perceived control, and well-being (i.e., positive affectivity, optimism) have been found to predict behavior in occupational change by facilitating openness to change. On the basis of this body of literature, we hypothesize that the degree of implementation of the educational standard reform (e.g., implementation of competence-oriented teaching and data use) can be predicted by openness to change, which in turn can be predicted by the dispositions mentioned above (see Fig. 1). Thus, Hypotheses 1-3 propose that self-efficacy, perceived control, and positive affectivity predict openness to change. Moreover, we expect that the degree of openness to change will predict the behavioral outcome, that is the amount of competence-oriented teaching and teachers' use of data feedback for classroom improvement (Hypotheses 4 and 5). Finally, we assume that, in accordance with the

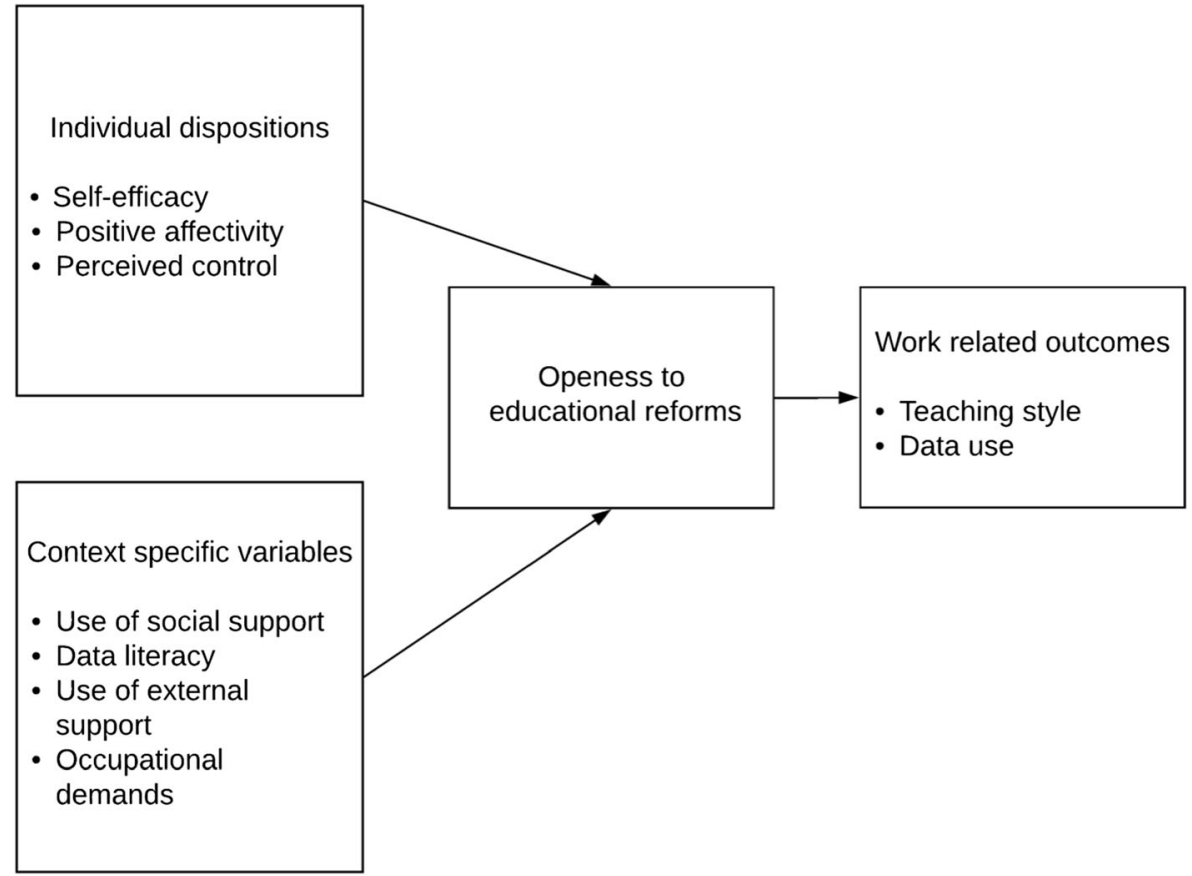

Fig. 1 Research model portraying the influence of dispositional and context-specific variables on behavioral outcome 
literature, also context-specific aspects will influence openness to change. We therefore control for context-specific characteristics, i.e., implementation information, occupational demands, and support, by assuming that favorable context-characteristics also facilitate openness to change, although to a lesser extent than dispositions (Hypotheses 6-8).

\section{Material and method}

\subsection{Participants}

The study at hand was part of a larger project investigating the implementation of educational reforms. We asked 1200 teachers at 320 primary schools to fill in paper and pencil questionnaires in the Austrian state of Upper Austria. The questionnaires included scales indexing individual characteristics (i.e., self-concept, positive affectivity, locus of control), openness to change, and outcome variables measuring teachers' behavior during change (i.e., implementation of a competence-based instruction and of data use) as well as context variables (i.e., use of social support, use of external support, occupational demands). It took about $40 \mathrm{~min}$ to fill in the full questionnaire (which included additional aspects that were not used in the present study). A sample of 318 teachers (27\% return rate) from 106 schools responded to the questionnaire. More than $50 \%$ of the participants claimed more than 15 years of professional experience.

\subsection{Instruments}

Table 1 in the Appendix contains measurement information and exemplary items of all constructs. Scales had good $(\alpha>.80)$ or acceptable reliability $(\alpha>.70$; Bacon et al. 1995; Nunnally 1978). The replication of the factor structures of the original scales was possible in all cases.

\subsubsection{Individual characteristics:}

Self-efficacy Occupational self-efficacy was captured by ten items of the teacher selfefficacy scale (Schwarzer and Schmitz 1999; Schmitz and Schwarzer 2000) which refer to teachers' beliefs about professional achievement, professional development, and social interaction with students, parents, and colleagues. On a scale from 1 (totally disagree) to 4 (totally agree), participants indicated to what extent they were able of mastering difficult situations (e.g., "I am able to enforce changes in teaching activities, even though colleagues are sceptical" or "I can impart contents to troublesome students"). Internal consistency of the scale including all items was high (Cronbach's $\alpha=.77$ ).

Positive affectivity According to Judge et al. (1999), positive affectivity represents a disposition typically manifested in characteristics such as well-being and satisfaction. We included an item indicating professional satisfaction ("Please indicate how satisfied you feel in your occupation as a teacher"), ranging from 1 (dissatisfied) to 4 (totally satisfied) as an indicator for well-being (see also Wright and Cropanzano 2000 for the same procedure). This builds on the idea that a person's well-being is predominantly influenced 
by his or her perception of the occupational situation; Brief et al. 1995; Wanberg et al. 1997; Paul and Batinic 2010). It should be noted that professional satisfaction does not capture all aspects of positive affectivity. Since occupational satisfaction and positive affectivity are highly correlated ( $r=.50$; Alarcon et al. 2009; Chang et al. 2012; Kaplan et al. 2009), have similar values in terms of temporal stability (Dormann and Zapf 2001; Staw and Ross 1985), and are assumed to build on the same genetic components (Arvey et al. 1989), occupational satisfaction indicates aspects of positive affectivity and is therefore an useful indicator in occupational research.

Perceived control The scale of Sachse et al. (2012) assesses the degree to which people believe they are in control of situations (internal locus of control). The scale has been adapted to the context of teachers by indexing through eight items how much pressure teachers perceived in aligning their work with others. Teachers were asked to assess to what extent ( $1=$ no pressure; $4=$ high pressure $)$ other individuals or groups of people put pressure on them arrange their work in a specific way. The directions read as follows: "Please indicate to what extent you feel pressured aligning your work by the following individuals/groups of persons: colleagues" etc. The scale showed high reliability (Cronbach's $\alpha=.81$ ). For further analyses, the scale was reversed: High values indicate high "internal control."

Openness to change It is assumed that reactions to change are facilitated by openness to change, which, in turn, is fostered by positive values of perceived control, positive affectivity, and self-efficacy. Similar to previous studies (i.e., Oreg 2006), teachers' openness to change was operationalized by a 10 -item scale introduced by Ditton et al. (2002) capturing teachers' attitudes towards performance standards and regular standard testing. The items of this scale were slightly adapted to make them fit to Austrian standard testing (e.g., "Educational standard testing should be conducted on a regular basis" or "Evaluating national standards in Austria is important for work at schools"). They were evaluated by teachers ranging from $1=$ strongly disagree to $4=$ strongly agree. Items 5 to 10 were negatively formulated and therefore reversed for scale analysis. The scale showed high internal consistency (Cronbach's $\alpha=.86$ ).

Behavior-related outcomes Changes in teacher behavior were measured by the amount to which teachers engaged in the goal behavior intended by the performance standards policy. Changes to competence-based teaching was assessed through the 3item scale "Competence orientation in teaching" by Richter et al. (2014) which is to capture the most important aspects of competence-oriented teaching (i.e., planning teaching according to performance standards and using competence-based teaching material; Neuweg 2015). On a 4-point scale ( $1=$ does not apply to $4=$ totally applies), teachers indicated the amount their teaching has changed towards more competenceoriented teaching after the introduction of performance standards (e.g., "my teaching is less content-oriented but more competence-oriented" or "I focus more on educational standards"). The scale showed sufficient consistency (Cronbach's $\alpha=.70$ ).

Changes in teaching as a consequence of data feedback were assessed by the 8 -item scale "Changes in the preparation of classroom teaching after data feedback" by Groß Ophoff (2013). On a 5-point scale, teachers indicated what teaching practices (e.g., 
"applying tasks adapted to individual competencies" or "repetition of contents which showed low performance in the test") they used more or less frequently ( $1=$ much less frequently to $5=$ much more frequently) due to the data feedback they had received. Reliability of the scale was sufficiently high (Cronbach's $\alpha=.76$ ).

\subsubsection{Context-specific variables}

Data literacy According to Koch (2011), Groß Ophoff (2013), and Helmke (2004), data-based classroom development can only be expected if teachers have sufficient empirical knowledge and understanding for reading and making sense of data feedback. Teachers' self-assessed data literacy was recorded using a 10-item scale for assessment comprehensibility (Grillitsch and Amtmann 2012), ranging from $1=$ not comprehensible at all to $4=$ well comprehensible. Responding to the initial question "How comprehensible do you evaluate the following information in the data feedback report" teachers rated items such as, e.g., "test performance of my class as compared to other classes in Austria" or "the variance of my class's achievement." Since almost all teachers in the sample said that they understood the feedback very well in all aspects (see Rieß and Zuber 2014, for similar results), this scale had to be excluded from the modeling due to a ceiling effect (with a strong right-hand distribution of the data; deviation from the normal distribution: K-S test $p<.001$ ) and to very low variance of the scale.

Use of external support Austrian schools were offered the opportunity to request external support for the interpretation of data feedback. Whether or not this "external support" ("feedback moderators" who provided information and competence training) was used and was recorded as a manifest variable with the response options "support used: yes/no." Variation in answers were sufficiently high (51\% of teachers claimed that they had external support at their school) to include this dichotomous variable in the model.

Use of social support Social support was operationalized by the question (Demski 2017) how often teachers discussed topics related to the educational standard reform (e.g., instruction, curricula, changes) with colleagues or supervisors at school, ranging from $1=$ a few times a year to $4=$ on a daily basis.

Occupational demands Occupational demands were measured by teachers' experience of stress and excessive work demands with an abridged 5-item scale according to Wacker (2008). The scale by Wacker (2009) was developed as a short version of wellestablished teacher stress measures (e.g., Kyriacou 2010; van Dick 2006), focussing on the most prominent stressors in German-speaking education systems, such as staff meetings, organizational matters, and educational reforms. Participants were asked to indicate the amount of stress they experienced at work from a 1 (totally disagree) to 4 (totally agree) scale (e.g., "due to the high amount of teachers meetings at school, I do not have enough time preparing my lessons" or "due to the high amount of organizational matters, I do not have enough time preparing my lessons"). Comparable to the original validation of the scale (Wacker 2008), the scale showed good internal consistency (Cronbach's $\alpha=.75$ ). 


\section{Results}

\subsection{Descriptive results}

More than $70 \%$ of the responding teachers agreed that their own self-efficacy was very high, while occupational satisfaction was evaluated distinctly lower with only $30 \%$ reporting the highest levels of occupational satisfaction. Similarly, only about $40 \%$ of the teachers reported a very high level of perceived control, whereas the majority indicated that they felt external pressure to align their work with others. Seventy-one percent of the teachers in this study said that they had implemented competence-based teaching on a regular basis. A considerably smaller number, only $27 \%$, indicated that they had frequently developed their classroom as a consequence of data feedback. Only $46 \%$ expressed a positive attitude towards this innovation. Regarding context variables, $51 \%$ of teachers reported that they had external support at their schools. Also, extensive social support was reported, almost $70 \%$ reported frequent interactions with colleagues or supervisors about educational standards.

\subsection{Statistical analysis}

To account for the instruments' measurement error, all analyses were conducted by means of latent variable modeling in Amos (Arbuckle 2014), estimating coefficients with maximum likelihood estimation. Compared to analysis based on mean scores by observed scores, latent variable modeling has the advantage of addressing the problem of measures' unreliability and, thus, leads to less biased parameter estimates. In this manuscript, cutoff values suggested by Little (2013), Hu and Bentler (1998), and Marsh et al. (2004) are taken into account to interpret results regarding how well the hypothesized model fit the data: $\chi^{2} / \mathrm{df}$ values $<3$ are usually used as acceptable models. Furthermore, models with a CFI $\geq .90$, TLI values $\geq .90$, RMSEA $\leq .08$, and SRMR $\leq .10$ are considered to adequately fit the data.

In the first step, the measurement models of the constructs were analyzed. A latent variable model with the correlated perceived control, self-concept, positive affectivity, openness to change, and the outcome variables competence-oriented teaching and data use showed a satisfactory fit to the data $\left(\chi^{2} / \mathrm{df}=1.69 ; \mathrm{CFI}=.92 ; \mathrm{TLI}=.90 ; \mathrm{RMSEA}=.05\right.$; SRMR = .05). Standardized factor loadings were between .31 and .85 (see Table 1).

The hypotheses presented above postulated that individual characteristics, i.e., high levels of locus of control, self-efficacy, and positive affectivity, will be associated with higher levels of openness to change (Hypotheses 1-3). Moreover, context-specific variables (e.g., social support, external support, and occupational demands) were also expected to be associated with openness to change, although to a lesser extent (Hypotheses 6-8). Hypotheses 4 and 5 stated that the attitude to the reform will relate to the outcome variables, namely the degree of competence-oriented teaching and data use for classroom improvement. The results are presented in Fig. 2.

The proposed model showed sufficient data fit $\left(\chi^{2} / \mathrm{df}=2.30 ; \mathrm{CFI}=.90 ; \mathrm{TLI}=.89\right.$; RMSEA = .06; SRMR =.07). In line with Hypotheses 1 and 2, higher levels of selfefficacy and positive affectivity were positively associated with openness to change (see Fig. 2). Contrary to our expectations, perceived control was not associated with teachers' openness to the reform (Hypothesis 3). As proposed, openness to change turned out to be a 


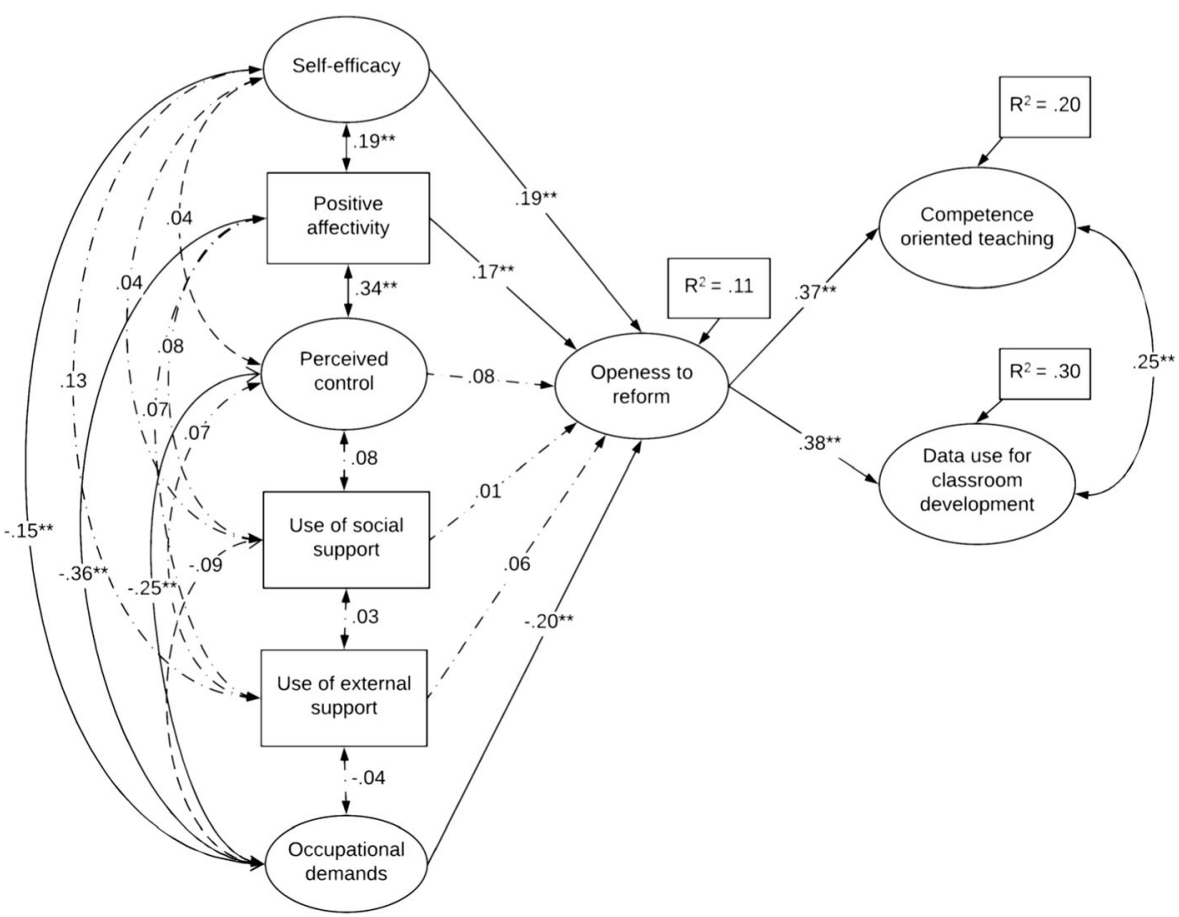

Fig. 2 Prediction of openness towards the educational standard reform and behavioral reactions by dispositions and contextual variables $\left(\chi^{2} / \mathrm{df}=2.30 ; \mathrm{CFI}=.90 ; \mathrm{TLI}=.89 ; \mathrm{RMSEA}=.06\right.$; SRMR $\left.=.07\right)$. Nonsignificant paths are drawn as dash-lines, significant paths $(* * p<.001 ; * p<.05)$ are drawn as full line

significant predictor of behavior. The behavioral outcome variables, competence-oriented teaching, and data use showed a strong positive association with openness to change (both coefficients $>.37$ ). Finally, there were hardly any context-specific associations with openness to change. While the use of social and external support did not predict openness to the reform, occupational demands negatively predicted openness to change. The lower occupational burdens, the more likely became openness to change. In the model, $20 \%$ of the implementation of the competence-based instruction and $30 \%$ of data use were explained by the predictor openness to change. However, very little variance of the construct openness to change was explained by the individual dispositions and contextual factors ( $11 \%$, calculation including non-significant paths).

\section{Discussion}

Complementing previous research on the role of individual characteristics in occupational change, the present study used three well-established personality traits to predict the degree of teachers' behavioral reactions to an educational reform, operationalized by the degree of use of competence-oriented teaching and data feedback for classroom development. The results of this study support three main conclusions: First, in line with the body of previous research some personal dispositions, in particular positive affectivity and selfefficacy proved to be important for building openness to the reform and thereby supporting the individuals' cooperation in the change processes. Teachers who make 
use of the reform and show the behavior intended by the reform seem to be primarily characterized by high levels of occupational satisfaction. To a lesser degree, also selfefficacy predicts change behavior: Those who consider themselves capable of mastering (difficult) situations build openness to the reform which in turn facilitates implementation behavior. Second, in contradiction to previous findings, perceived control does not contribute to individuals behavioral reactions in this study. Third, contrary to our hypothesis and to the main thrust of literature, we were not able to demonstrate the predicted context-specific effects on openness to change. Neither the use of social nor external support predict openness to change, only occupational burdens are negatively associated with openness to change. Teachers experiencing high levels of occupational demands were less likely to develop a positive attitude towards the reform.

\subsection{Theoretical considerations}

In the present study, only two of three dispositions predicted the formation of "openness to change." There are several theoretical as well as methodological reasons to be considered. Locus of control has been shown to be influenced by frequency, length, and intensity of experiences in specific contexts (most prominently in health context; Lohaus 1992): The longer, the more intense and the more often someone is exposed to unpleasant experiences, the higher the probability that the person will perceive low levels of control and consequently care less about situations. Since teaching and the work in classrooms and schools are frequently undergoing changes which are controlled by external actors (i.e., administration or politics), teachers may perceive low levels of control and, in consequence, care less about the reform (which would be indicated by negative or neutral attitudes to the reform). This interpretation is partly supported by the data since the majority of teachers report high levels of perceived pressure to change their behavior and low levels of acceptance of the reform. If this interpretation makes sense, one would also expect that teachers with long-time work experience report less control (contrary to a "work socialisation hypothesis" which would expect that "perceived control" grows with experience).

The idea that long-term exposure to change in the educational system might diminish perceived control could also be transferred to the contextual variables and give some explanation to the lack of effects of support structures in our data. Given the fact that teachers had already been confronted with educational standards for 3 years, the supportive power of social interaction might have regressed after long exposition to the reform and its support structure. On the other hand, there have been mixed results also in previous studies: Rieß and Zuber (2014) found that external support did not enhance participation in Austrian educational standard reform, while there is also evidence that support structures facilitate the implementation of educational reforms (Schildkamp and Ehren 2012). In a long-term perspective, one would expect that implementation support is conducive for the overall goal of the policy, for the improvement of teaching and learning processes and of student results.

Second, the study at hand has measured the influence of person factors on the effects intended by the performance standard policy. However, the literature suggests that there may also be several unintended effects (e.g., strategic and symbolic use of this policy). Possibly, the amount of perceived control would be more important for predicting behavior when it comes to unintended effects rather than intended effects. Previous studies support this argument: it has been shown that unintended use of feedback data is 
most likely when the perceived pressure is very high (von der Embse 2017). Exploring this issue constitutes a worthwhile goal for future research.

Third, also methodical issues need to be considered regarding the influence of perceived pressure. With respect to dispositional characteristics for change, we assume that the scales self-efficacy, positive affectivity, and perceived pressures are highly relevant for the context of our study. Moreover, self-efficacy and affectivity are correlated, as predicted by the literature (Gu and Day 2007). However, perceived pressure as measured in this study may not represent the broader construct of locus of control as proposed by Rotter (1966). According to previous research, one would expect that all these variables are correlated as they index "resilience" (Gu and Day 2007; Major et al. 1998). Since perceived control was not correlated with self-efficacy and did not predict openness to change, future studies should test a different approach to the measurement of locus of control constructs (such as the scales of Rotter 1966). Even though the applied scale achieved good reliability, the construct is either more heterogeneous than expected or is not optimally assessed by those eight items suggested by the scale authors.

\subsection{Limitations}

The study at hand has certain limitations that provide opportunities for future research. Another look at the variables included in the study may be worthwhile. The low explanations of variances ( $R^{2}$ from .11 to .30$)$, in particular, the low levels of variance explaining openness to change $\left(R^{2}=.11\right)$, suggest that additional information is required to explain "openness to change" within the context of educational reforms. First, it seems useful to include a broader concept of positive affectivity and locus of control. Since positive affectivity was only indexed by occupational satisfaction - as one indicator of positive affectivity - including broader scales, encompassing optimism etc. might increase variance. Second, even though cognitive adaption theory has been shown to be a valid predictor of behavior in change contexts, previous studies point to further variables that could also be considered: First, implementation studies of changes in teaching found that teacher beliefs are important predictors as well. According to Zeitler et al. (2012), understanding and implementing the concept of competence-based teaching was easier for teachers with a constructivist understanding of teaching and learning, while teachers with instructionist views were more likely to avoid competence-based changes. This is also backed by results of Wan (2015), who reported that the implementation of differentiated instruction was strongly associated with attitude formation which, in turn, facilitated implementation.

Second, attitudes towards educational reforms have been reported to be predominantly negative and/or highly ambivalent (e.g., Ungar 2016) which is driven by the fact that elements and role changes of educational reforms are often evaluated as ambiguous. Judge et al. (1999) suggested that the disposition "tolerance for ambiguity" (the tendency to perceive ambiguous situations as tolerable) is related to several aspects of coping with changes (e.g., Rush et al. 1995) whereas intolerance for ambiguity is related to the perception of ambiguous situations as sources of threat. It is quite likely that "tolerance for ambiguity" might add to the explanatory power of dispositions on attitude and behavior in educational reforms.

Third, studies focussing on coping with educational reforms, in particular, with reforms including high accountability pressure, suggest that, besides self-efficacy, individual coping strategies predict how change is dealt with. However, these variables do not necessarily influence the formation of attitudes such as openness to change; rather, they influence 
cognitive-emotional evaluation processes which predict behavior. For example, Callan et al. (1994) found that ineffective (emotion-focussed) copers were more prone to anxiety in the wake of organizational change, while successful coping with organizational change was positively related to job performance (Judge et al. 1999). Moreover, coping has been found to mediate the relationship between personality and job performance in educational reforms (von der Embse et al. 2016) and also in other fields (Judge et al. 1999).

Fourth, "perceived pressure" has also been studied under the concept of attribution. Attributions refer to perceived causes that individuals select or construct for events in their lives (Weiner 1994). Attributions are made along three causal dimensions; locus of control (internal vs. external causes), controllability (controllable causes such as skills vs. luck), and stability (do causes change over time?). A basic assumption of attribution theory is that a person's understanding of the causes of events influences his or her future actions. Motivation for action will increase if the causes are perceived to be internal and controllable. There are first indications that attribution might also play a critical role in educational standard policy, in particular for data feedback use. Teachers and school supervisors tend to attribute student performance to external factors (e.g., students' lack of competence; Schneewind 2007; Kohler 2004). Tresch (2007) provided some differentiation of this argument by showing that teachers mainly used external attribution for below-average outcomes, while above-average results were given both internal and external attributions. This corresponds to the theoretical expectation that internal attribution will be preferred after success, while external attributions are given after failures (e.g., Musch and Bröder 1999). External attribution may provide some emotional relief, but may also inhibit further reflection on possible courses of action when it comes to making use of data feedback (Koch 2011). Therefore, it seems worthwhile including this concept in further studies.

Another important methodological point has to be taken into account when interpreting the findings of this study. The data used in this study is solely based on teachers' selfreported perceptions. While this is a reasonable approach for several constructs portrayed in the model (i.e., individual characteristics), this may not be the case for the measurement of behaviors and competences. In our results, this became visible as "data literacy," a previous identified key variable for data use (e.g., Schildkamp and Ehren 2012), could not be included in the model, since teacher self-reports produced massive ceiling effects. A potential explanation is that this finding reflects the true situation (i.e., teachers' high data literacy and/or easily readable data feedback reports). This argument could be supported by the sampling error in this study. As only $27 \%$ of teachers responded, the sample might comprise only those teachers who understand the feedback best, the other who did not understand the feedback did not respond). However, previous studies suggest otherwise: Teachers seem to overestimate their data literacy in self- reports (for an overview, see Koch 2011). The study at hand captured data literacy with eight items, focussing on different aspects of the Austrian data feedback report. Nevertheless, this scale did not turn out to be sufficiently valid to avoid ceiling effects. Further studies on educational change processes should therefore use different approaches for measuring goal behavior and competences (e.g., by externally observing goal behavior or externally assessing data competences).

Finally, limitations in the interpretation of the outcome scales need to be considered. Teachers were asked to indicate to what extent they took up educational standard reform, indicated by their amount of competence-based teaching and data-use. However, within this operationalization of behavior, the reasons teachers implement changes remain unclear. When teachers responded that they had paid more attention to competence-based teaching 
as opposed to content-based teaching, they might simply react to policy waves (since they are more open to these waves). But, they might have also positively responded to this change because it is deeply in line with their beliefs about teaching practices. Thus, the interpretation of the current findings remains on a superficial level. Dispositions, occupational demands, and openness to change contribute to behavioral reactions; however, we do not know which level of underlying behavioral motivation is addressed.

\subsection{Implications}

The study at hand constitutes a first step of linking several person characteristics to the intended outcomes of a specific educational reform, the performance standards policy. The results clearly underline that it is worthwhile to include person factors of teachers into studying processes and effects of implementing performance standards and data feedback. The study suggests that, in line with previous research, teachers' behavioral reactions to educational reforms are at least to some extent dependent on factors that are difficult to change as dispositions are relatively stable over time. Teachers who have a positive selfconcept and high levels of positive affectivity will be more likely to build up a positive attitude towards an educational reform and more likely to show changes in teaching behavior according to the intentions of the reform. One potential consequence lies in the question whether it would be useful to test and select teachers more carefully before entering training, or, at least, before determining the pilot groups of a reform. Although there is an extensive body of literature supporting the reliability and validity of the personal dispositions included in this study, few of these characteristics have been studied in a selection context. Thus, although the results of the present study are suggestive for applying these variables in selection processes for teacher training or pilot group selection, they do not directly demonstrate the validity of these dispositions in selection processes in the educational context. Moreover, those characteristics that predict positive behavior during change might not be equally valid for predicting constructive behavior during periods of less change (however, there is some evidence for at least some correlation between typical job performance and self-efficacy; see Pierce et al. 1989).

Is it impossible to successfully develop the - comparatively stable - dispositions considered in this study during teacher careers, e.g., through teacher training programs etc.? Education, in particular higher education (Dahmann and Anger 2014), has been found to crucially influence personality characteristics by fostering favorable characteristics with regard to the specific profession. Thus, one might hypothesize that also teacher education can have some leeway for developing favorable dispositions which enhance coping with change. The study at hand is certainly limited with respect to explaining the origins of dispositions; nevertheless, it seems to be worthwhile exploring the influence of teacher education on teachers' personal dispositions and on their coping with reforms. In sum, educational reforms are pursued in all countries and no change to this situation is expected. While previous research on educational change has often focussed on the policy and organizational level, this paper links educational change to individual characteristics as suggested by cognitive adaption theory. However, further research is needed to account for individual difference and contextual factors related to change in more detail and to asses and extend the generalizability of the results of the current study.

Funding Information Open access funding provided by Johannes Kepler University Linz. 


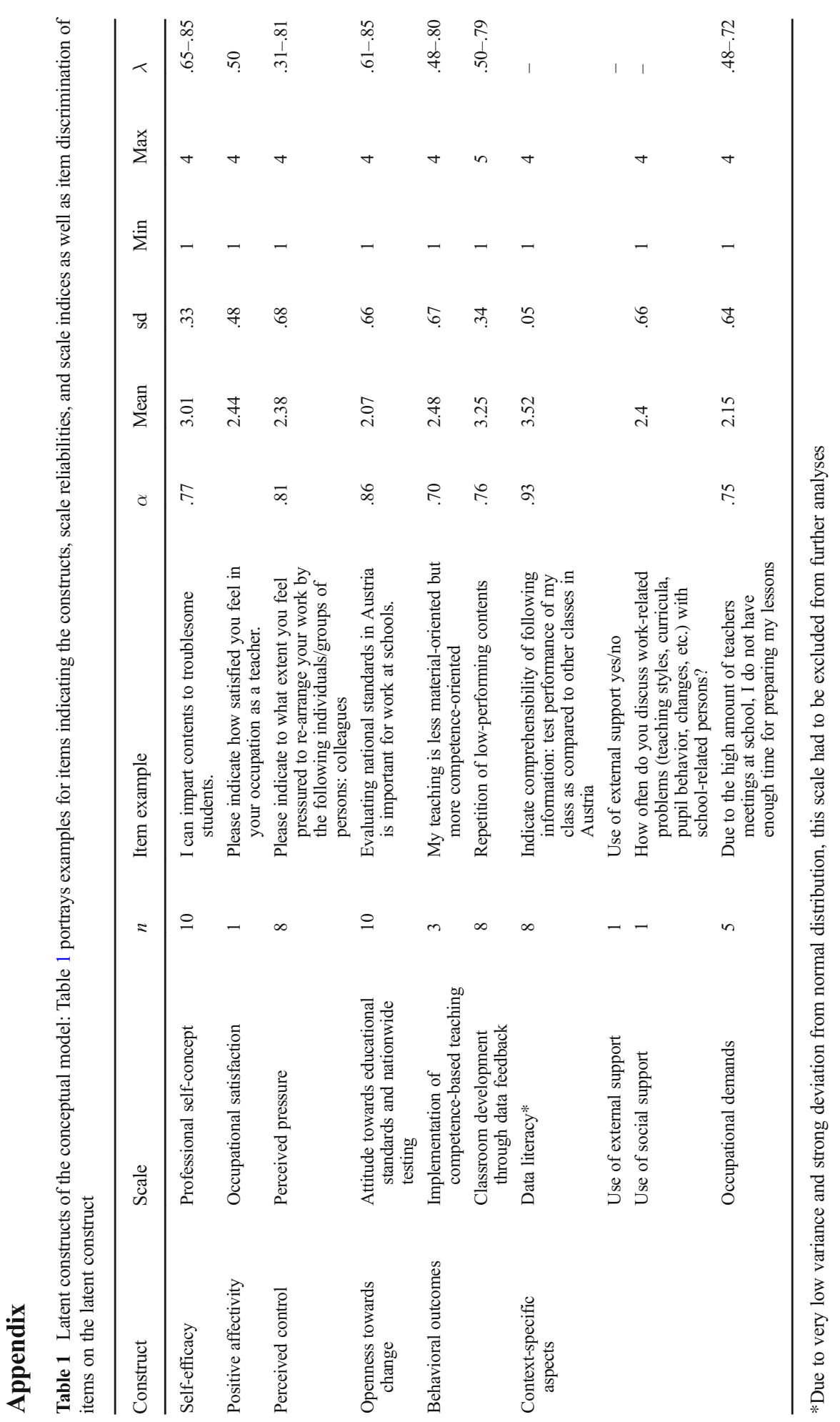


Open Access This article is distributed under the terms of the Creative Commons Attribution 4.0 International License (http://creativecommons.org/licenses/by/4.0/), which permits unrestricted use, distribution, and reproduction in any medium, provided you give appropriate credit to the original author(s) and the source, provide a link to the Creative Commons license, and indicate if changes were made.

\section{References}

Alarcon, G., Eschleman, K. J., \& Bowling, N. A. (2009). Relationship between personality variables and burnout: a meta-analysis. Work \& Stress, 23, 244-263.

Altrichter, H., \& Gamsjäger, M. (2017). A conceptual model for research in performance standard policies. Nordic Journal of Studies in Education Policy, 3(1), 6-20.

Altrichter, H., \& Kanape-Willingshofer, A. (2012). Bildungsstandards und externe Überprüfung von Schülerkompetenzen: Mögliche Beiträge externer Messungen zur Erreichung der Qualitätsziele der Schule. In B. Herzog-Punzenberger (Ed.), Nationaler Bildungsbericht. Österreich 2012. Band 2 (pp. 355-394). Leykam: Graz.

Altrichter, H., Brüsemeister, T., \& Heinrich, M. (2005). Merkmale und Fragen einer Governance-Reform am Beispiel des österreichischen Schulwesens. Characteristics and queries of reforming school governance: the case of Austria. Österreichische Zeitschrift für Soziologie, 30(4), 6-28.

Altrichter, H., Moosbrugger, R., \& Zuber, J. (2016). Schul- und Unterrichtsentwicklung durch Datenrückmeldung. In H. Altrichter \& K. Maag Merki (Eds.), Handbuch Neue Steuerung im Schulsystem (pp. 235-277). Wiesbaden: Springer VS.

Anderson, S., Leithwood, K., \& Strauss, T. (2010). Leading data use in schools: organizational conditions and practices at the school and district levels. Leadership and Policy in Schools, 9, 292-327.

Arbuckle, J. L. (2014). Amos (Version 23.0) [Computer Program]. Chicago: IBM SPSS.

Arvey, R.D., Bouchard, T.J., Segal, N.L., \& Abraham, LM., (1989). Job satisfaction: environmental and genetic components: Journal of Applied Psychology, 74(2), 187-192.

Ashford, S.J. (1988). Individual strategies for coping with stress during organizational transitions. The Journal of Applied Behavioral Science, 24, 19-36.

Ashforth, B. E., \& Lee, R. T. (1990). Defensive behavior in organizations: a preliminary model. Human Relations, 43, 621-648.

Aspinwall, L. G., \& Taylor, S. E. (1992). Modeling cognitive adaption: a longitudinal investigation of the impact of individual differences and coping on college adjustment and performance. Journal of Personality and Social Psychology, 63(6), 989-1003.

Bacon, D.R., Sauer, P.L. \& Young, M. (1995). Composite reliability in structural equations modeling. Educational and Psychological Measurement, 55, 394-406.

Bandura, A. (1997). Self-efficacy. The exercise of control. New York: Freeman.

BIFIE [Bundesinstitut für Bildungsforschung, Innovation und Entwicklung des österreichischen Schulwesens] (2012). Bildungsstandard [Educational standards]. https://www.bifie.at/bildungsstandards. Accessed 5 June 2017.

Blum, W. (2012). Einführung. In W. Blum (Hrsg.), Bildungsstandards Mathematik: konkret. Sekundarstufe I: Aufgabenbeispiele, Unterrichtsanregungen, Fortbildungsideen (S. 14-33). Berlin: Cornelsen.

Brief, A., Konovsky, M. A., Goodwin, R., \& Link, K. (1995). Inferring the meaning of work from the effects of unemployment. Journal of Applied Social Psychology, 25(8), 693-711.

Brown, G. T. L., \& Harris, L. R. (2009). Unintended consequences of using tests to improve learning: how improvement-oriented resources heighten conceptions of assessment as school accountability. Journal of Multi-Disciplinary Evaluation, 12(6), 68-91.

Budner, S. (1962). Intolerance of ambiguity as a personality variable. Journal of Personality, 30(1), 29-50.

Callan, V. J., Terry, D. J., \& Schweitzer, R. (1994). Coping resources, coping strategies and adjustment to organizational change: direct or buffering effects? Work and Stress, 8, 372-383.

Campbell, C., \& Levine, B. (2009). Using data to support educational improvement. Educational Assessment, Evaluation and Accountability, 21, 47-65.

Chang, C. H., Ferris, D. L., Johnson, R. E., Rosen, C. C., \& Tan, J. A. (2012). Core self-evaluations: a review and evaluation of the literature. Journal of Management, 38(1), 81-128.

Coe, R. (1998). Can feedback improve teaching? A review of the social science literature with a view to identifying the conditions under which giving feedback to teachers will result in improved performance. Research Papers in Education, 13(19), 42-66.

Crino, M. D. (1994). Employee sabotage: a random or preventable phenomenon? Journal of Managerial Issues, 6(3), 311-330. 
Dahmann, S., \& Anger, S. (2014). The impact of education on personality. IZE. Available online: http:// ftp.iza.org/dp8139.pdf, Accessed 20 September 2017.

Datnow, A., \& Hubbard, L. (2016). Teacher capacity for and beliefs about data-driven decision making: a literature review of international research. Journal of Educational Change, 17(1), 7-28.

Demski, D. (2017). Evidenzbasierte Schulentwicklung. Empirische Analyse eines Steuerungsparadigmas. Wiesbaden: Springer.

Ditton, H., \& Merz, D. (1999). Fragebogen für Lehrerinnen und Lehrer (QUaSSU - Qualitätssicherung in Schule und Unterricht). https://www.quassu.net/Lehohunt1.pdf. Accessed 5 June 2017.

Ditton, H., \& Merz, D. (2000). Qualität von Schule und Unterricht. In Bericht über die Voruntersuchung in Bayern. Eichstätt: Katholische Universität/Universität Osnabrück.

Ditton, H., Merz, D., \& Edelhäusser, T. (2002). Einstellungen von Lehrkräften und Schulleiter/innen zu zentralen Testuntersuchungen an Schulen. Empirische Pädagogik, 16(1), 17-33.

Dormann, C., \& Zapf, D. (2001). Job satisfaction: a meta-analysis of stabilities. Journal of Organizational Behavior, 22, 483-504.

Dubs, R. (2006). Bildungsstandards: Das Problem der schulpraktischen Umsetzung. Netzwerk. Die Zeitschrift für Wirtschaftsbildung, 1, 18-29.

Grillitsch, M. (2010). Bildungsstandards auf dem Weg in die Praxis. Ergebnisse einer Befragung von Lehrkräften und Schulleiter/innen der Sekundarstufe I zur Rezeption der Bildungsstandards und deren Implementation (BIFIEReport 6/ 2010). Graz: Leykam. https://www.bifie.at/buch/1235. Accessed 5 June 2017.

Grillitsch, M. \& Amtmann, E. (2012). Rezeption der Bildungsstandards und Erfahrungen mit der Ergebnisrückmeldung. Befunde der Begleitforschung zur Baseline-Testung auf der 4. Schulstufe. Graz: BIFIE. https://www.bifie.at/node/2484. Accessed 5 June 2017.

Groß Ophoff, J. (2013). Lernstandserhebungen: Reflexion und Nutzung. Münster: Waxmann.

Gu, Q., \& Day, C. (2007). Teachers resilience: a necessary condition for effectiveness. Teaching and Teacher Education, 23, 1302-1316.

Härenstam, A., Bejerot, E., Leijon, O., Schéele, P., \& Waldenström, K. (2004). Multilevel analyses of organizational change and working conditions in public and private sector. European Journal of Work and Organizational Psychology, 13(3), 305-343.

Hellrung, K., \& Hartig, J. (2013). Understanding and using feedback: a review of empirical studies concerning feedback form external evaluations to teachers. Educational Research Review, 9, 174-190.

Helmke, A. (2004). Von der Evaluation zur Innovation: Pädagogische Nutzbarmachung von Vergleichsarbeiten in der Grundschule. SEMINAR - Lehrerbildung und Schule, 2, 90-112.

Holahan, C. J., \& Moos, R. H. (1987). Personal and contextual determinants of coping strategies. Journal of Personality and Social Psychology, 52, 946-955.

Hosenfeld, I., Koch, U., Groß Ophoff, J., \& Scherthan, F. (2008). Projekt VERA: Ergebnisorientierte Unterrichtsentwicklung durch internetgestützte externe Evaluation? In A. Breiter \& E. Stauke (Eds.), Schulinformationssysteme und datengestützte Entscheidungsprozesse (pp. 49-59). Bern: Peter Lange.

Hu, L. T., \& Bentler, P. M. (1998). Fit indices in covariance structure modeling: sensitivity to under parameterized model misspecification. Psychological Methods, 3, 424-453.

Judge, T. A., Thoresen, C. J., Pucik, V., \& Welbourne, T. M. (1999). Managerial coping with organizational change: a dispositional perspective. Journal of Applied Psychology, 84(1), 107-122.

Kaplan S., Bradley J.C, Luchman, J.N.,\& Haynes D. (2009). On the role of positive and negative affectivity in job performance: a meta-analytic investigation. Journal of Applied Psychology, 94(1), 162-176.

Kersting, M. (2003). Augenscheinvalidität (face validity). In K. D. Kubinger \& R. S. Jäger (Eds.), Schlüsselbegriffe der Psychologischen Diagnostik (pp. 54-55). Weinheim: Beltz.

Koch, U. (2011). Verstehen Lehrkräfte Rückmeldungen aus Vergleichsarbeiten? Datenkompetenz von Lehrkräften und die Nutzung von Ergebnisrückmeldungen aus Vergleichsarbeiten? Münster: Waxmann.

Kohler, B. (2004). Zur Rezeption externer Evaluation durch Lehrkräfte, Eltern sowie Beamte der Schulaufsicht. Empirische Pädagogik, 18(1), 18-39.

Kühle, B. (2010). Zentrale Lernstandserhebungen - Ergebnisorientierte Unterrichtsentwicklung? Schule Strategien beim Umgang mit Ergebnissen aus den Schulrückmeldungen im Kontext der ersten Lernstandserhebungen 2004/2005 in Nordrhein-Westfalen. Berlin: Verlag Dr. Köster.

Kühle, B., \& Peek, R. (2007). Lernstandserhebungen in Nordrhein-Westfalen. Evaluationsbefunde zur Rezeption und zum Umgang mit Ergebnisrückmeldungen in Schulen. In I. Hosenfeld \& J. Groß Ophoff (Eds.), Nutzung und Nutzen von Evaluationsstudien in Schule und Unterricht (pp. 428-447). Landau: Verlag Empirische Pädagogik.

Kuper, H., \& Hartung, V. (2007). Überzeugungen zur Verwendung des Wissens aus Lernstanderhebungen. Eine professionstheoretische Analyse. Zeitschrift für Erziehungswissenschaft, 2, 214-229.

Kyriacou, C. (2010). Teacher stress: directions for future research. Educational Review, 53(1), 27-35. 
Lau, C.-M., \& Woodman, R. W. (1995). Understanding organizational change: a schematic perspective. Academy of Management Journal, 38(2), 537-554.

Lersch, R. (2010). Wie unterrichtet man Kompetenzen? Didaktik und Praxis kompetenzfördernden Unterrichts. Wiesbaden: Hessisches Kultusministerium, Institut für Qualitätsentwicklung.

Lewin, K. (1951). Field theory in social science. New York: Springer.

Little, T. D. (2013). Longitudinal structural equation modeling. Guilford Press: New York.

Lohaus, A. (1992). Kontrollüberzeugung zu Gesundheit und Krankheit [Perceived control towards health and illness]. Zeitschrift für Klinische Psychologie, 21, 76-87.

Maag Merki, K. (2016). Theoretische und empirische Analysen der Effektivität von Bildungsstandards, standardbezogenen Lernstandserhebungen und zentralen Abschlussprüfungen. In H. Altrichter \& K. Maag Merki (Eds.), Handbuch Neue Steuerung im Schulsystem (S. 151-181). Wiesbaden: VS.

Maier, U. (2009a). Wie gehen Lehrerinnen und Lehrer mit Vergleichsarbeiten um? Erlangen: Schneider Verlag.

Maier, U. (2009b). Testen und dann? - Ergebnisse einer qualitativen Lehrerbefragung zur individualdiagnostischen Funktion von Vergleichsarbeiten. Empirische Pädagogik, 23, 191-207.

Maier, U., \& Kuper, H. (2012). Vergleichsarbeiten als Instrumente der Qualitätsentwicklung an Schulen. Überblick zum Forschungsstand. Die Deutsche Schule, 104, 88-99.

Maier, U., \& Rauin, U. (2006). Vergleichsarbeiten - Hilfe zur Unterrichtsentwicklung? Zentrale Lernstandserhebungen aus Sicht baden-württembergischer Lehrkräfte. Die Deutsche Schule, 98(4), 403-421.

Major, B., Richards, C., Cooper, M. L., Cozzarelli, C., \& Zubek, J. (1998). Personal resilience, cognitive appraisal and coping: an integrative model of adjustment to abortion. Journal of Personality and Social Psychology, 74, 735-752.

Marsh, H. W., Wen, Z., \& Hau, K. (2004). Structural equation models of latent interactions: evaluation of alternative estimation strategies and indicator construction. Psychological Methods, 9, 275-300.

Means, B., Padilla, C., DeBarger, A., \& Bakia, M. (2009). Implementing data-informed decision making in schools - teacher access, Supports and Use. Report prepared for U.S. Department of Education, Office of Planning, Evaluation and Policy Development: https://www.sri.com/work/publications/implementingdata-informed-decision-making-schools-teacher-access-supports-and-use. Accessed September 202017.

Miller, V. D., Johnson, J. R., \& Grau, J. (1994). Antecedents to willingness to participate in a planned organizational change. Journal of Applied Communication Research, 11, 365-386.

Musch, J., \& Bröder, A. (1999). Ergebnisabhängig asymmetrischer Attributionsverhalten: Motivationale Verzerrung oder rationale Informationsverarbeitung? Zeitschrift für Sozialpsychologie, 30(4), 246-254.

Nachtigall, C., \& Hellrung, K. (2013). Zur zeitlichen Entwicklung der Rezeption von Vergleichsarbeiten. Empirische Pädagogik, 27, 423-441.

Nelson, A., Cooper, C. L., \& Jackson, P. R. (1995). Uncertainty amidst change: the impact of privatization on employee job satisfaction and well-being. Journal of Occupational and Organizational Psychology, 68, 57-71.

Neuweg, G.H. (2015). Unterrichtsplanung unter besonderer Berücksichtigung des kaufmännischen Unterrichts. Eine Arbeitshilfe (nicht nur) für Einsteigerinnen und Einsteiger (Version 3.0). Linz: Eigenvervielfältigung.

Nord, W. R., \& Jermier, J. M. (1994). Overcoming resistance to resistance: insights form a study of the shadows. Public Administration Quarterly, 17(4), 396.

Nunnally, J.C. (1978). Psychometric theory (2nd ed.). New York: McGraw-Hill.

Oreg, S. (2006). Personality, context, and resistance to organizational change. European Journal of Work and Organizational Psychology, 15(1), 73-101.

Ozga, J., \& Jones, R. (2006). Travelling and embedded policy: the case of knowledge transfer. Journal of Education Policy, 21(1), 1-17.

Pant, H. A., Vock, M., Pöhlmann, C., \& Köller, O. (2008). Offenheit für Innovationen: Befunde aus einer Studie zur Rezeption der Bildungsstandards bei Lehrkräften und Zusammenhänge mit Schülerleistungen. Zeitschrift für Pädagogik, 56(6), 827-845.

Patton, M. Q. (2003). Utilization-focussed evaluation. In T. Kellaghan \& D. L. Stufflebeam (Eds.), International handbook of educational evaluation (p. 223-244). Dordrecht: Kluwer.

Paul, K. I., \& Batinic, B. (2010). The need for work: Jahoda's latent functions of employment in a representative sample of the German population. Journal of Organizational Behaviour, 31, 45-64.

Peek, R. (2004). Qualitätsuntersuchung an Schulen zum Unterricht in Mathematik (QUASUM). Klassenbezogene Ergebnisrückmeldungen und ihre Rezeption in Brandenburger Schulen. Empirische Pädagogik, 18(1), 82-114.

Peek, R., \& Dobbelstein, P. (2006). Benchmarks als Input für die Schulentwicklung - das Beispiel der Lernstandeserhebungen in Nordrhein-Westfalen. In H. Kuper \& J. Schneewind (Eds.), Rückmeldungen und Rezeption von Forschungsergebnissen - Zur Verwendung wissenschaftlichen Wissens im Bildungssystem (pp. 41-58). Münster: Waxmann. 
Pierce, J. L., Gardner, D. G., Cummings, L. L., \& Dunham, R. B. (1989). Organization-based selfesteem: Construct definition, measurement, and validation. Academy of Management Journal, 32, 622-648.

Reusser, K. (2014). Kompetenzorientierung als Leitbegriff der Didaktik. Beiträge zur Lehrerbildung, 32(3), 325-339.

Richter, D., Böhme, K., Becker, M., Pant, H. A., \& Stanat, P. (2014). Überzeugungen von Lehrkräften zu den Funktionen von Vergleichsarbeiten. Zeitschrift für Pädagogik, 60(2), 225-244.

Rieß, C., \& Zuber, J. (2014). Rezeption und Nutzung von Ergebnissen der Bildungsstandardüberprüfung in Mathematik auf der 8. Schulstufe unter Berücksichtigung der Rückmeldemoderation. BIFIE Report 02/ 2012. https://www.bifie.at/system/files/d1/E_BIST_M8_RM_RMM_20140623.pdf. Accessed 5 June 2017.

Rotter, J. B. (1966). Generalized expectancies for internal versus external control of reinforcement. Psychological Monographs, 80(1), 1-28.

Rush, M. C., Schoel, W. A., \& Barnard, S. M. (1995). Psychological resiliency in the public sector: "hardiness" and pressure for change. Journal of Vocational Behavior, 46, 17-39.

Ryan, R. M., \& Brown, K. W. (2005). Legislating competence. High-stakes-testing policies and their relations with psychological theories and research. In A. J. Elliot \& C. S. Dweck (Eds.), Handbook of competence and motivation (pp. 987-1006). New York: Guilford Press.

Ryan, S. V., von der Embse, N. P., Pendergast, L. L., Saeki, E., Segool, N., \& Schwing, S. (2017). Leaving the teaching profession: the role of teacher stress and educational psychology in the schools accountability policies on turnover intent. Teaching and Teacher Education, 66(11), 1-11.

Sachse, K., Kocaj, A., \& Kretschmann, J. (IQB) (2012). Sprachliche Kompetenzen im Ländervergleich. Skalenhandbuch. https://www.iqb.hu-berlin.de/fdz/studies/IQB-LV_2008-9/CodebookDE_LFB.pdf. Accessed 5 June 2017.

Schellenbach-Zell, J., Rürup, M., Fussangel, K., \& Gräsel, C. (2008). Bedingungen erfolgreichen Transfers am Beispiel von Chemie im Kontext. In R. Demuth, C. Gräsel, I. Parchmann, \& B. Ralle (Eds.), Chemie im Kontext. Von der Innovation zur nachhaltigen Verbreitung eines Unterrichtskonzepts (pp. 83-123). Waxmann: Münster.

Schildkamp, K., \& Ehren, M. C. M. (2012). From intuition to data-based decision making in Dutch secondary schools? In K. Schildkamp, M. Lai, \& L. Earl (Eds.), Data-based decision making in education: challenges and opportunities (pp. 49-67). Dordrecht: Springer.

Schildkamp, K., Poortman, C. L., \& Handelzalts, A. (2016). Data teams for school improvement. School Effectiveness and School Improvement, 27(2), 228-254.

Schmitz, G. S., \& Schwarzer, R. (2000). Perceived self-efficacy of teachers: longitudinal findings with a new instrument. Zeitschrift für Pädagogische Psychologie, 14(1), 12-25.

Schneewind, J. (2007). Wie Lehrkräfte mit Ergebnisrückmeldungen aus Schulleistungsstudien umgehen. Ergebnisse aus Befragungen von Berliner Grundschullehrerinnen. Berlin: Freie Universität.

Schrader, F.-W., \& Helmke, A. (2004). Von der Evaluation zur Innovation? Die Rezeptionsstudie WALZER: Ergebnisse der Lehrerbefragung. Empirische Pädagogik, 18(1), 140-161.

Schwarzer, R., \& Schmitz, G. S. (1999). Lehrer-Selbstwirksamkeit. Dokumentation der Skala LehrerSelbstwirksamkeit (WirkLehr). Leibniz-Zentrum für Psychologische Information und Dokumentation (ZPID). [Online publication]. http://www.zpid.de/pub/tests/pt_1003tWirkLehr.pdf. Accessed 5 June 2017.

Schweiger, D. M., \& DeNisi, A. S. (1991). Communication with employees following a merger: a longitudinal. Academy of Management Journal, 34(1), 110-115.

Shaw, J. B., Fields, M., Thacker, J., \& Fisher, C. D. (1993). The availability of personal and external coping resources: impacts on job stress and employee attitudes during organizational restructuring. Work and Stress: An International Journal of Work, Health \& Organisations, 7(3), 229-246.

Skarlicki, D. P., \& Folger, R. (1997). Retaliation in the workplace: the roles of distributive, procedural and interactional justice. Journal of Applied Psychology, 82(3), 434-443.

Slovic, P. (1972). Information processing, situation specificity and the generality of risk taking behaviour. Journal of Personality and Social Psychology, 22, 128-134.

Staw, B. M., \& Ross, J. (1985). Stability in the midst of change: a dispositional approach to job attitudes. Journal of Applied Psychology, 70(3), 469-480.

Suprayogi, M. N., Valcke, M., \& Godwin, R. (2017). Teachers and their implementation of differentiated instruction in the classroom. Teaching and Teacher Education, 67, 291-301.

Sutin, A. R., \& Costa, P. T. (2010). Reciprocal influences of personality and job characteristics across middle adulthood. Journal of Personality, 78, 257-288.

Taylor, S. E. (1983). Adjustment to threatening events: a theory of cognitive adaptation. American Psychologist, 38, 1161-1173.

Taylor, S. E., \& Brown, J. D. (1988). Illusion and well-being: a social psychological perspective on mental health. Psychological Bulletin, 103, 193-210. 
Trempler, K., Schellenbach-Zell, J., \& Gräsel, C. (2012). Der Einfluss der Motivation von Lehrpersonen auf den Transfer von Innovationen. In M. Rürup \& I. Bormann (Eds.), Innovationen im Bildungswesen. Analytische Zugänge und empirische Befunde (pp. 329-347). Wiesbaden: VS Verlag für Sozialwissenschaften.

Tresch, S. (2007). Potenzial Leistungstest: Wie Lehrerinnen und Lehrer Ergebnisrückmeldungen zur Sicherung und Steigerung ihrer Unterrichtsqualität nutzen [How teachers use performance feedback to ensure and increase the quality of teaching] Bern: hep.

Tummers, L., Steijn, B., \& Bekkers, V. (2012). Explaining the willingness of public professionals to implement public policies: content, context, and personality characteristics. Public Administration, 90, 716-736.

Ungar, O. A. (2016). Understanding teachers' attitude toward educational reforms through metaphors. International Journal of Educational Research, 77, 117-127.

van Dick, R. (2006). Stress und Arbeitszufriedenheit bei Lehrerinnen und Lehrern: Zwischen "Horrorjob" und Erfüllung [Stress and job satisfaction of teachers: between ,horror job” and fulfilment]. Marburg: Tectum.

Vanhoof, J., Verhaeghe, P., van Petegem, P., \& Valcke, M. (2013). Improving data literacy in schools: lessons from the school feedback project. Dordrecht: Springer.

von der Embse, N. P. (2017). The psychological and instructional consequences of high-stakes accountability. Psychology of Education Review, 41(1), 45-50.

von der Embse, N., Schoemann, A. M., Kilgus, S. P., Wicoff, M., \& Bowler, M. (2016). The influence of testbased accountability policies on teacher stress and instructional practices: a moderated mediation model. Educational Psychology, 37(3), 312-331.

Wacker, A. (2008). Bildungsstandards als Steuerungselemente der Bildungsplanung. Bad Heilbrunn: Klinkhardt.

Wan, S.Y. (2015). Differentiated instruction: Hon Kong prospective teachers' teaching efficacy and beliefs. Teachers and Teaching: Theory and Practice, 22(2), 1-29.

Wanberg, C. R., \& Banas, J. T. (2000). Predictors and outcomes of openness to changes in a reorganizing workplace. Journal of Applied Psychology, 85(1), 132-142.

Wanberg, C. R., Griffiths, R. F., \& Gavin, M. B. (1997). Time structure and unemployment: a longitudinal investigation. Journal of Occupational and Organizational Psychology, 70, 75-95.

Wayman, J. C., Cho, V., Jimerson, J. B., \& Spikes, D. D. (2012). District-wide effects on data use in the classroom. Education Policy Analysis Archives, 20(25), 1-31.

Weiner, B. (1994). Motivationspsychologie. Weinheim: Beltz.

Weinert, F. E. (2001). Vergleichende Leistungsmessung in Schulen - eine umstrittene Selbstverständlichkeit. In F. E. Weinert (Eds.), Leistungsmessungen in Schulen (pp. 17-31). Weinheim und Basel: Beltz.

Windzio, M., Sackmann, R. \& Martens, K. (2005). Types of governance in education - a quantitative analysis (TranState Working Papers, 25). Universität Bremen: Sonderforschungsbereich 597 „Staatlichkeit im Wandel“ http://www.econstor.eu/dspace/bitstream/10419/28275/1/501321926.PDF. Accessed 5 June 2017.

Wright, T. A., \& Cropanzano, R. (2000). Psychological well-being and job satisfaction as predictors of job performance. Journal of Occupational Health Psychology, 5, 84-94.

Zeitler, S., Heller, N., \& Asbrand, B. (2012). Bildungsstandards in der Schule. In Eine rekonstruktive Studie zur Implementation der Bildungsstandards. Münster: Waxmann.

Zuckerman, M., \& Link, K. (1968). Construct validity for the sensation-seeking scale. Journal of Consulting and Clinical Psychology, 32(4), 420-426. 